\title{
Occupational Fatalities Due to Mammal-Related Accidents in Japan, 2000-2019
}

\author{
Atsushi Hioki, $\mathrm{MD}, \mathrm{PhD}^{1}$; Ryoichi Inaba, $\mathrm{MD}, \mathrm{PhD}^{2}$ \\ ${ }^{1}$ Department of Internal Medicine, Matsunami General Hospital, Gifu, Japan; ${ }^{2}$ Department of Occupational Health, Gifu University Graduate \\ School of Medicine, Gifu, Japan
}

\begin{abstract}
Introduction-Animal-related fatal accidents occur annually while individuals are outside working. This study intended to evaluate the trends of occupational fatal accidents related to mammals and compare them with nonoccupational accidents.

Methods - We collected occupational and nonoccupational fatalities related to mammals between 2000 and 2019 from data on fatal occupational accident cases certified by the Ministry of Health, Labor and Welfare, Japan, in addition to other statistics from relevant ministries, media reports such as newspapers, and academic case reports.

Results-A total of 109 fatal accidents related to mammals were confirmed as occurring during work, and 129 were confirmed as taking place outside of work. Of the former, accidents among livestock farmers and horse racing-related workers accounted for about half. Among the accidents not related to work, dog attacks, infectious diseases from cats or dogs, traffic accidents with wild animals, and bear attacks during wild vegetable picking were common. Deaths from infectious diseases caused by dogs and cats have rarely been reported in the mass media.

Conclusions-Although the number of fatal occupational accidents related to mammals is not large, we concluded that it is necessary to continue preventive measures centered on accidents at livestock farms and in horse racing-related workplaces. It is also necessary to inform people about the risks of infectious diseases mediated by dogs and cats.
\end{abstract}

Keywords: occupational accident, animal attack, animal handler, infection

\section{Introduction}

Fatal accidents due to animals are caused directly by attacks such as biting, scratching, stinging, kicking, hitting, or crushing; indirectly by venom ${ }^{1}$ or pathogens ${ }^{2}$; or by traffic accidents involving animals. ${ }^{3}$ Direct incidents are reported to have occurred during work, during hobbies or recreation, or in nature. ${ }^{4-6}$ Occupational fatal accidents among animal handlers can occur at farms, in animal exhibition facilities, in sport facilities, or in amusement facilities. Occupational accidents can also occur among non-animal handlers by wild mammals, such as in attacks subsequent to unexpected encounters with animals or animal-related vehicle collisions.

Corresponding author: Atsushi Hioki, MD, PhD, Department of Internal Medicine, Matsunami General Hospital, 185-1 Dendai, Kasamatsu-cho, Gifu 501-6062, Japan; e-mail: hioki.a3@mghg.jp.

Submitted for publication June 2020.

Accepted for publication September 2020.
Mammals are more familiar to humans as livestock and pets. Fatal accidents due to mammals are sometimes reported in the media in Japan, especially in cases of instantaneous death. However, there are no specialized statistics for occupational accidents caused by mammals. Statistics on cases that were approved by occupational accident compensation insurance ${ }^{7,8}$ do not include data on insurance nonsubscribers. Mortality data from vital statistics $^{9}$ do not distinguish among causal mammals (other than rats and dogs) and might not be sufficient to describe occupational situations around deaths; individual information has not been published. Vital statistics also include Japanese deaths abroad. From the perspective of occupational health, we think it is useful for employers, occupational physicians, and workers to share how mammal-related fatal accidents occur at work among animal handlers and non-animal handlers.

In this report, we investigated the trends in occupational mammal-related fatal accidents in occupations such 
as livestock farming, as well as at horse racing-related facilities or zoos in Japan. We compared these trends with deaths outside of work, based on individual data from government statistics on occupational accidents and animal welfare and management, as well as mass media information and academic case reports.

\section{Methods}

We analyzed fatalities in mammal-related accidents in Japan from 2000 to 2019. At first, the cases were collected from 4 government statistics databases: 1) fatal occupational accidents that were verified under the industrial accident compensation insurance act ${ }^{7}$ or the local public officers accident compensation act, ${ }^{8}$ 2) fatalities caused by specified animals that are likely to inflict injury on people, ${ }^{10} 3$ ) fatal accidents during hunting, ${ }^{11}$ and 4) forestry work-related mortalities. ${ }^{12}$ The second group of cases was gathered by prefectures (local governments in Japan) under the prefectural ordinances on welfare and management of animals and has been sent to Ministry of the Environment since April 2009. The third group of cases was also sent from prefectures to the Ministry of the Environment as part of wildlife-related statistical reports. The fourth group of cases was collected from prefectures and local safety managers for the Forestry and Timber Manufacturing Safety and Health Association.

Additional information was surveyed from PubMed, Ichushi-Web, newspaper article databases (Asahi Shimbun, Chunichi Shimbun/Tokyo Shimbun, Nikkei Telecom), other websites on industrial safety-related public organizations, and animal-related organizations or news agencies, using various combinations of the terms "attack," "bite," "crush," "hit," "kick," "restive," "rush," "scratch," "sting," "fall from a horse," "collision," "infection," "animal," "cattle," "pig," "horse," "bear," "tiger," "lion," "wild boar," "deer," "serow [Japanese antelope]," "workplace," "livestock farmer," "raiser," "trainer," "horse racing," "equestrian club," or "zoo" in English and Japanese. In this study, we included nonprofessional hunters victimized during harmful animal elimination work, such as bear hunting, among occupational fatalities. Accidents due to mammals among self-sufficient farmers were included as occupational fatalities. To compare occupational fatalities due to mammals with nonoccupational fatalities, we collected nonoccupational fatalities caused by mammals simultaneously.

We collected information on the date and time of the accident; the sex, age, and profession of the victim; the species of mammal that had harmed humans; the behavior of the victim when the accident occurred; the place of the accident; and the source of news or reports. If the time or place of mammal-related accidents was not available, the reporting year or location of the medical institution was used. These data were also compared with the number of deaths in the vital statistics based on death certificates, ${ }^{9}$ such as "bitten by rodent [ICD-10 code W53]," "bitten or struck by dog [W54]," "contact with other mammals [W55]," and "contact with marine animal [W56]." Fish such as sharks were excluded from marine animals.

Data are presented as the mean $\pm \mathrm{SD}$ with range. To see the trends in accident occurrence, we compared the average values of the number of accidents every $5 \mathrm{y}$ using a 1-way analysis of variance. Differences between the 2 groups were evaluated via t-test for the continuous variables and via $\chi^{2}$ test for the categorical variables. $P<0.05$ was considered significant. Statistical analysis was performed using Microsoft Office Excel 2007 SP3 (Microsoft, Seattle, WA).

\section{Results}

From the government statistical data, we obtained the following data: 1) fatal occupational accidents: 58 cases; 2) fatalities caused by specified animals: 14 cases; 3 ) fatalities during hunting: 9 cases; and 4) forestry work-related cases: 1 confirmed. In the literature search, 9 reports $^{13-21}$ on 13 fatalities from infectious diseases related to mammal attacks and 5 reports $^{22-26}$ on 11 deaths from direct mammal attacks were confirmed. There were 4 fatalities in government reports and 186 media reports on 188 accidental deaths.

With matching of duplicate cases based on the date of the accident, animal species, and victim's age and address, 77 and 32 occupational fatalities related to mammals were confirmed among animal handlers and non-animal handlers, respectively, in Japan from 2000 through 2019. Another 129 nonoccupational fatalities were collected in this period. All cases obtained from statistics of deaths from specified animals overlapped with other information. In 2 motorcycle collisions and 1 accident while walking on a mountain road, it was not determined whether the injurious animal was a boar or a deer. The number of work-related fatal accidents due to animal attacks among animal handlers and non-animal handlers was $3.9 \pm 1.8(1-8)$ and $1.6 \pm 1.1(0-5)$ per year, respectively (Figure 1). There was no significant difference in the number of accidents across 4 time periods (every $5 \mathrm{y}$ ). Compared to the vital statistics figures, our data tended to have low numbers in the 2000s, especially in 2003 and 2005. These are primarily due to low numbers of deaths from contact with mammals other than rats or dogs. 


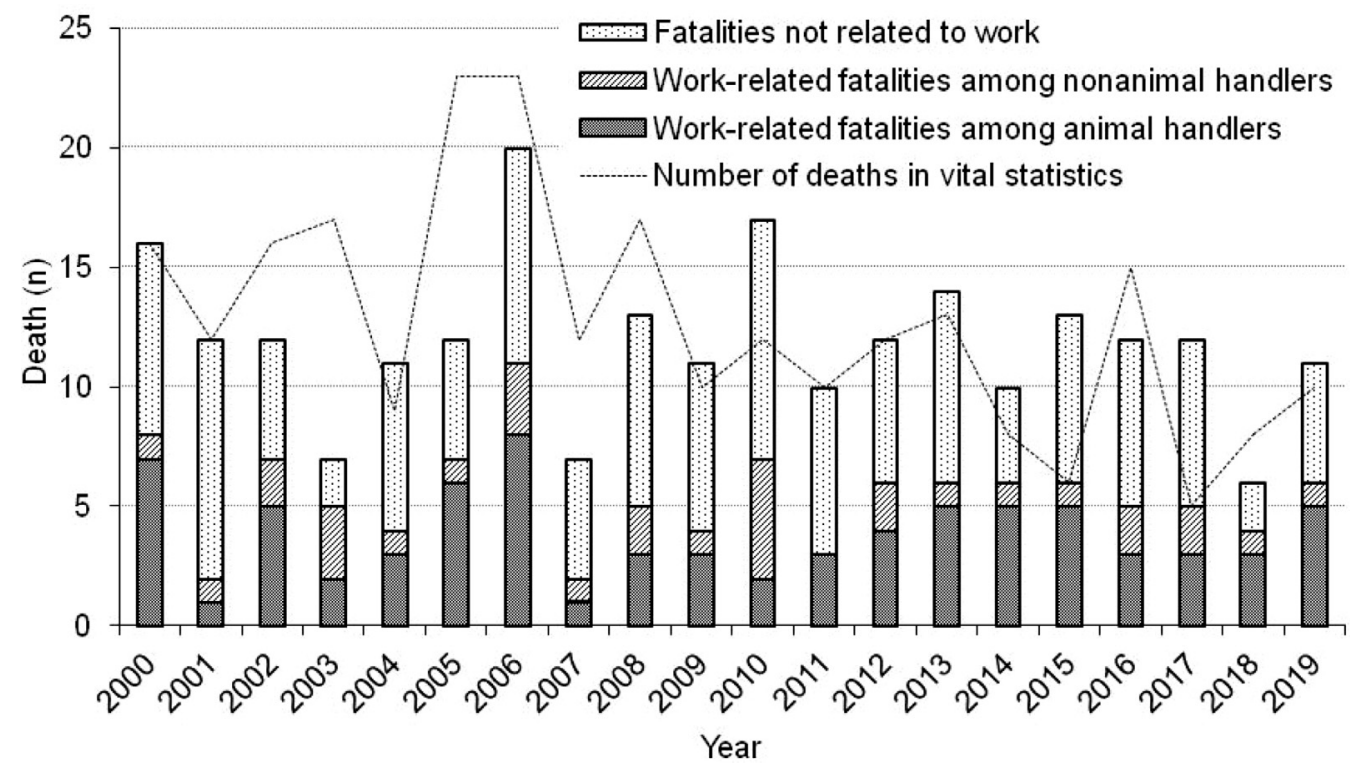

Figure 1. Changes in the number of fatal accidents caused by mammals during and outside of work. The bar graph shows collected accidental mortality cases due to mammal-related accidents, and the line graph shows the number of deaths by mammals in the vital statistics based on death certificates.

Accidents by cattle or horses on livestock farms and accidents involved horses in horse race-related workplaces accounted for about half $(27$ and $25 \%$, respectively) of all occupational fatalities (Table 1). The number of fatal accidents in zoos was $12(11 \%)$. For other work-related fatal accidents among animal handlers, 3 meat industry workers were rushed while moving cattle; an employee at an animal lender was attacked by a tiger while feeding the animal; a dog breeder was attacked while taking care of dogs; a riding school instructor died after a fall from a horse; a civil servant was kicked to death during a horse inspection; an educational and research institution staff member was attacked by a horse; and a part-time animal keeper was attacked by a bear bred by his employer.

For occupational fatalities among non-animal handlers, accidents caused by wild boar, bear, or dogs while farming were the most frequent, accounting for $12 \%$ of all accidents during work. Seven hunters (6\%) were attacked by bears during a bear extermination task. Four drivers and 4 newspapermen died in traffic accidents while avoiding or colliding with wild boar, deer, horses, or dogs. A hotel staff member was attacked by a bear while picking edible wild plants for guests; a fisherman was bounced by a minke whale which unexpectedly became tangled in fishing nets; a forestry worker was attacked by a bear during tree felling; and a police officer was bitten by a ferret that he was trying to capture. The officer developed cellulitis 3 mo later and died 16 y later due to the bite (the details are not known because the information does not come from an academic case report). It was only this last instance in which the individual died of an infectious disease due to a mammalrelated accident during work.

Leading nonoccupational fatal accidents were as follows; 33 people died after an attack by a dog, cat, deer, or bear in their daily life around home; 30 people died in deer- and other animal-related traffic accidents; 23 people were killed by a bear or wild boar while collecting wild vegetables in the mountains; 10 hunters were attacked by wild boar, bear, or deer while hunting; and 9 people died in accidents while horse riding. One person was bitten by a pet hamster and died of anaphylactic shock. There were 13 cases of death due to infectious diseases caused by animal attacks outside of work; the pathogens were Capnocytophaga canimorsus (6 cases from dogs, 5 cases from cats), Pasteurella multocida (1 case from a cat), and severe fever with thrombocytopenia syndrome virus (1 case from a cat).

Table 2 shows the changes in the number verified occupational fatalities and the certification rates among those who died from mammal-related accidents during work. Of the work-related fatal accidents, $64 \%$ of animal handlers and $28 \%$ of non-animal handlers had been verified as occupational accidents. The certification rate of livestock farmers tended to be low among animal handlers throughout the years. Among the non-animal handlers, none of the farmers and bear extermination workers have been certified as occupational accidents. Overall, the age of workers who were verified as 
Table 1. Fatal accidents from 2000 to 2019 by animal species and behavior at the time of the accident

\begin{tabular}{|c|c|c|c|c|c|c|c|c|c|c|c|c|c|c|c|c|c|}
\hline $\begin{array}{l}\text { Work or behavior at the time } \\
\text { of accident }\end{array}$ & Bear & Horse & Cattle & Dog & Deer & $\begin{array}{l}\text { Wild } \\
\text { boar }\end{array}$ & $\begin{array}{l}\text { Wild } \\
\text { boar } \\
\text { or Deer }{ }^{a}\end{array}$ & Cat & $\begin{array}{l}\text { Raccoon } \\
\operatorname{dog}^{b}\end{array}$ & Elephant & Tiger & Lion & Rhino & Whale & Ferret & Hamster & Total \\
\hline Work-related fatalities & 20 & 33 & & 4 & 2 & 9 & 1 & $\mathbf{0}$ & $\mathbf{0}$ & 3 & 3 & 1 & 1 & 1 & 1 & $\mathbf{0}$ & 109 \\
\hline $\begin{array}{l}\text { Fatal accidents due to handling } \\
\text { mammals }\end{array}$ & 6 & 32 & 30 & 1 & 0 & 0 & 0 & 0 & 0 & 3 & 3 & 1 & 1 & 0 & 0 & 0 & 77 \\
\hline Livestock farming & 0 & 2 & 27 & 0 & 0 & 0 & 0 & 0 & 0 & 0 & 0 & 0 & 0 & 0 & 0 & 0 & 29 \\
\hline Horse racing-related work & 0 & 27 & 0 & 0 & 0 & 0 & 0 & 0 & 0 & 0 & 0 & 0 & 0 & 0 & 0 & 0 & 27 \\
\hline Zoo work & 5 & 0 & 0 & 0 & 0 & 0 & 0 & 0 & 0 & 3 & 2 & 1 & 1 & 0 & 0 & 0 & 12 \\
\hline Meat industry work & 0 & 1 & 2 & 0 & 0 & 0 & 0 & 0 & 0 & 0 & 0 & 0 & 0 & 0 & 0 & 0 & 3 \\
\hline Other livestock raising service & 1 & 2 & 1 & 1 & 0 & 0 & 0 & 0 & 0 & 0 & 1 & 0 & 0 & 0 & 0 & 0 & 6 \\
\hline $\begin{array}{l}\text { Fatal accidents among non-animal } \\
\text { handlers }\end{array}$ & 14 & 1 & 0 & 3 & 2 & 9 & 1 & 0 & 0 & 0 & 0 & 0 & 0 & 1 & 1 & 0 & 32 \\
\hline Farm work & 5 & 0 & 0 & 1 & 0 & 7 & 0 & 0 & 0 & 0 & 0 & 0 & 0 & 0 & 0 & 0 & 13 \\
\hline Bear removal & 7 & 0 & 0 & 0 & 0 & 0 & 0 & 0 & 0 & 0 & 0 & 0 & 0 & 0 & 0 & 0 & 7 \\
\hline Newspaper delivery & 0 & 1 & 0 & 1 & 1 & 0 & 1 & 0 & 0 & 0 & 0 & 0 & 0 & 0 & 0 & 0 & 4 \\
\hline Transportation & 0 & 0 & 0 & 1 & 1 & 2 & 0 & 0 & 0 & 0 & 0 & 0 & 0 & 0 & 0 & 0 & 4 \\
\hline Others & 2 & 0 & 0 & 0 & 0 & 0 & 0 & 0 & 0 & 0 & 0 & 0 & 0 & 1 & 1 & 0 & 4 \\
\hline Other fatalities & 31 & 14 & 4 & 29 & 23 & 14 & 2 & 7 & 4 & $\mathbf{0}$ & $\mathbf{0}$ & $\mathbf{0}$ & $\mathbf{0}$ & $\mathbf{0}$ & $\mathbf{0}$ & $\mathbf{1}$ & 129 \\
\hline Family life & 3 & 0 & 0 & 22 & 2 & 0 & 0 & 6 & 0 & 0 & 0 & 0 & 0 & 0 & 0 & 0 & 33 \\
\hline While riding a vehicle & 0 & 1 & 0 & 1 & 20 & 3 & 1 & 0 & 4 & 0 & 0 & 0 & 0 & 0 & 0 & 0 & 30 \\
\hline Wild vegetable picking & 21 & 0 & 0 & 1 & 0 & 1 & 0 & 0 & 0 & 0 & 0 & 0 & 0 & 0 & 0 & 0 & 23 \\
\hline Hobby hunting & 1 & 0 & 0 & 0 & 1 & 8 & 0 & 0 & 0 & 0 & 0 & 0 & 0 & 0 & 0 & 0 & 10 \\
\hline Horse riding & 0 & 9 & 0 & 0 & 0 & 0 & 0 & 0 & 0 & 0 & 0 & 0 & 0 & 0 & 0 & 0 & 9 \\
\hline Other hobbies and amusements & 3 & 4 & 4 & 1 & 0 & 1 & 0 & 0 & 0 & 0 & 0 & 0 & 0 & 0 & 0 & 1 & 14 \\
\hline Unknown & 3 & 0 & 0 & 4 & 0 & 1 & 1 & 1 & 0 & 0 & 0 & 0 & 0 & 0 & 0 & 0 & 10 \\
\hline Total & 51 & 47 & 34 & 33 & 25 & 23 & 3 & 7 & 4 & 3 & 3 & 1 & $\mathbf{1}$ & $\mathbf{1}$ & $\mathbf{1}$ & $\mathbf{1}$ & 238 \\
\hline
\end{tabular}

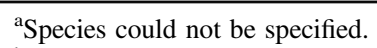

${ }^{\mathrm{b}}$ Nyctereutes procyonoides. 
Table 2. Number and certification rate (\%) of occupational fatalities due to mammal-related accidents during 4 time periods

\begin{tabular}{|c|c|c|c|c|c|}
\hline Work or behavior at the time of accident & $2000-2004$ & $2005-2009$ & $2010-2014$ & $2015-2019$ & Total \\
\hline \multicolumn{6}{|l|}{ Work-related fatalities } \\
\hline Fatal accidents due to handling mammals & $14(78)$ & $12(57)$ & $12(63)$ & $11(58)$ & $49(64)$ \\
\hline Livestock farming & $2(67)$ & $3(33)$ & $5(50)$ & $4(57)$ & $14(48)$ \\
\hline Horse racing-related work & $9(75)$ & $4(67)$ & $3(60)$ & $4(100)$ & $20(74)$ \\
\hline Zoo work & $1(100)$ & $3(75)$ & $3(100)$ & $3(75)$ & $10(83)$ \\
\hline Meat industry work & 0 & $2(100)$ & 0 & $0(0)$ & $2(67)$ \\
\hline Other livestock raising service & $2(100)$ & 0 & $1(100)$ & $0(0)$ & $3(50)$ \\
\hline Fatal accidents among non-animal handlers & $3(38)$ & $2(25)$ & $2(22)$ & $2(29)$ & $9(28)$ \\
\hline Farm work & $0(0)$ & $0(0)$ & $0(0)$ & $0(0)$ & $0(0)$ \\
\hline Bear removal & $0(0)$ & $0(0)$ & $0(0)$ & 0 & $0(0)$ \\
\hline Newspaper delivery & $1(50)$ & 0 & 0 & $1(50)$ & $2(50)$ \\
\hline Transportation & $1(100)$ & $1(100)$ & $1(50)$ & 0 & $3(75)$ \\
\hline Others & $1(100)$ & $1(100)$ & $1(100)$ & $1(100)$ & $4(100)$ \\
\hline Total & $17(65)$ & $14(48)$ & $14(50)$ & $13(50)$ & $58(54)$ \\
\hline
\end{tabular}

occupational fatalities was $51 \pm 15$ y $(20-75, \mathrm{n}=38)$, in contrast to $63 \pm 14(20-88, \mathrm{n}=51)$ for those who were not certified $(P<0.001)$. The age of livestock farmers who were verified as occupational fatalities $(54 \pm 9$ y; 36-67, $\mathrm{n}=11$ ) was lower than that of those who were not certified $(66 \pm 11 ; 48-86, \mathrm{n}=16, P<0.05)$. The ages of farmers and bear exterminators were $74 \pm 7$ y $(63-88, n=12)$ and $70 \pm 9$ $(59-82, \mathrm{n}=7)$, respectively.

Table 3 shows the sources of information on fatal accidents. Newspapers and other media covered $79 \%$ of the total, but a low proportion reported about accidents involving horse racing-related workers. Most (13 of 14) of the deaths due to infectious diseases were reported in academic case reports, and only 2 cases were also published in the media.

Regarding the time of the accident, there were no notable characteristics except that newspaper delivery was often early in the morning. As for the month of the accident, the number of accidents at livestock farms was high in November (24\%); the incidents during picking of edible wild plants were concentrated from April to June and October. In Hokkaido, whose residents accounted for $4 \%$ of the Japanese population among Japan's 47 prefectures during the study period, work-related accidents and other accidents accounted for the highest percentages, at 13 and $20 \%$ in the country, respectively (both $P<0.001$ ).

\section{Discussion}

The annual incidence of work-related fatalities due to mammals showed no significant change over 20 y, varying from 1 to 8 in animal handlers and from 0 to 5 in nonhandlers. Several organizations are taking steps to prevent accidents in the workplace. However, the number of accidents is not large, and it might be difficult to avoid rare accidents.

The highest proportion of occupational fatalities due to mammals among animal handlers was mainly caused by cattle and horses in livestock farms, followed by horses in horse race-related workplaces and by various species of mammals in zoos. It is necessary to continue measures to prevent these accidents. To reduce occupational accidents in farming, the Ministry of Agriculture, Forestry and Fisheries in Japan has been taking countermeasures to prevent accidents that are known and deeply understood by farmers ${ }^{27}$ by analyzing incidents and accidents collected all over the country. For example, accident prevention measures include not surprising cattle and checking the condition of cattle. In contrast, there is little information on accident prevention in local horse race-related institutes. ${ }^{28}$ As a part of labor standards, inspection offices that have horse racing-related facilities within their jurisdictional district have provided necessary advice. ${ }^{29,30}$ Among the fatal accidents at zoos, in the case in which 2 animal keepers were attacked and killed by brown bears in a bear park, it was determined that the management of the bear and the facilities by the facility owners was insufficient. Criminal responsibility was pursued. Since then, there have been fatal accidents in several zoos, and the Ministry of the Environment issued a notice regarding the care and storage of animals and has called for the safety of visitors and employees. ${ }^{31} \mathrm{We}$ think that it is necessary for employers, occupational physicians, and workers to share such information on these various occurrences to prevent future accidents.

Of the accidents among non-animal handlers, most farmers killed by wild bears, wild boars, or dogs were elderly. Aging of the agricultural population and accidents involving the elderly are issues in Japan. ${ }^{27}$ Bear 
Table 3. Sources of information on fatal accidents associated with mammals

\begin{tabular}{|c|c|c|c|c|c|c|c|}
\hline $\begin{array}{l}\text { Work or behavior at the time } \\
\text { of accident }\end{array}$ & $\begin{array}{l}\text { Newspapers } \\
\text { and other } \\
\text { media, } n(\%)\end{array}$ & $\begin{array}{l}\text { Occupational } \\
\text { accident } \\
\text { certification }^{a}\end{array}$ & $\begin{array}{l}\text { Academic } \\
\text { case } \\
\text { reports }\end{array}$ & $\begin{array}{l}\text { Statistics } \\
\text { on specified } \\
\text { animals }^{b}\end{array}$ & $\begin{array}{l}\text { Statistics } \\
\text { on hunting }^{c}\end{array}$ & $\begin{array}{l}\text { Other } \\
\text { statistics } \\
\text { and reports }^{d}\end{array}$ & Total \\
\hline Work-related fatalities & $77(71)$ & 58 & 3 & 6 & 1 & 3 & 109 \\
\hline $\begin{array}{l}\text { Fatal accidents due to handling } \\
\text { mammals }\end{array}$ & $49(64)$ & 49 & 2 & 6 & 0 & 2 & 77 \\
\hline Livestock farming & $20(69)$ & 14 & 0 & 0 & 0 & 2 & 29 \\
\hline Horse racing-related work & $12(44)$ & 20 & 0 & 0 & 0 & 0 & 27 \\
\hline Zoo work & $12(100)$ & 10 & 2 & 4 & 0 & 0 & 12 \\
\hline Meat industry work & $1(33)$ & 2 & 0 & 0 & 0 & 0 & 3 \\
\hline Other livestock-raising service & $4(67)$ & 3 & 0 & 2 & 0 & 0 & 6 \\
\hline $\begin{array}{r}\text { Fatal accidents among } \\
\text { non-animal handlers }\end{array}$ & $28(90)$ & 9 & 1 & 0 & 1 & 1 & 32 \\
\hline Farm work & $13(100)$ & 0 & 1 & 0 & 0 & 0 & 13 \\
\hline Bear removal & $7(100)$ & 0 & 0 & 0 & 1 & 0 & 7 \\
\hline Newspaper delivery & $3(75)$ & 2 & 0 & 0 & 0 & 0 & 4 \\
\hline Transportation & $1(25)$ & 3 & 0 & 0 & 0 & 0 & 4 \\
\hline Others & $4(100)$ & 4 & 0 & 0 & 0 & 1 & 4 \\
\hline Fatal accidents outside of work & $111(85)$ & $\mathbf{0}$ & 21 & 8 & 8 & 2 & 130 \\
\hline Family life & $21(64)$ & 0 & 14 & 5 & 1 & 0 & 33 \\
\hline While riding a vehicle & $30(100)$ & 0 & 0 & 1 & 0 & 0 & 30 \\
\hline Wild vegetable picking & $23(100)$ & 0 & 5 & 1 & 0 & 0 & 23 \\
\hline Hobby hunting & $7(70)$ & 0 & 0 & 0 & 7 & 0 & 10 \\
\hline Horse riding & $9(100)$ & 0 & 0 & 0 & 0 & 0 & 9 \\
\hline Other hobbies and amusements & $14(100)$ & 0 & 2 & 1 & 0 & 0 & 14 \\
\hline Unknown & $7(70)$ & 0 & 0 & 0 & 0 & 2 & 10 \\
\hline Total, n (\%) & 188 (79) & $58(24)$ & $24(10)$ & $14(6)$ & $9(4)$ & $5(1)$ & 238 \\
\hline
\end{tabular}

extermination hunters are also aging. ${ }^{11}$ The bear hunter's work is not a primary occupation, but a volunteer effort to remove harmful bears.

As for wild animals, brown bears (Ursus arctos yesoensis) living in Hokkaido, black bears (Ursus thibetanus japonicus) living in Honshu and Shikoku, and wild boars (Sus scrofa) living in Honshu, Shikoku, Kyushu, and the Nansei islands occasionally encounter and attack people. Deaths caused by bears are the most common in May through June and in October. The former is the time when people pick bamboo shoots or other wild vegetables, and the latter is when mushrooms are picked. For bears, the former is also the time when female bears are with cubs. An increase in bear attacks has been reported with climate change and changes in habitat, such as changes in food. ${ }^{23}$ Similarly, wild boars are appearing in the human habitation zone and causing harm to people and crops. ${ }^{32}$ Four of the boar fatalities were due to boars attacking a trap. Extreme caution is required.

Of the 27 cases of direct damage caused by dog attacks, 11 cases $(41 \%)$ were due to Tosa dogs. This dog is a dangerous breed used in dog fighting, and strict management by breeders is desired. In Japan, only some local governments have enacted an ordinance that specifies dogs according to their breed, body type, bite history, and so forth and requires some to be kept caged to prevent accidents.

Of work-related fatal accidents, $64 \%$ of animal handlers and $28 \%$ of nonhandlers experienced certified occupational accidents. Those who have not been in certified occupational accidents include farmers who did not participate in the industrial accident compensation insurance and horsemen who are not eligible for the insurance. In Japan, employers are obliged to join industrial accident insurance, but farmers are not obligated to join and voluntarily enroll. It is suggested that older livestock farmers did not have insurance. Among the non-animal handlers, farmers may not have insurance because there are few accidents, and bear exterminators do not have insurance because they are only involved in temporary volunteer work. Both groups tended to be older.

Among these accidents, those involving wildlife were frequently published in newspapers and other media. This 
may be because newspapers and other media obtain information on accidents mainly from the police. ${ }^{33}$ On the other hand, deaths from infections related to animals were rarely reported in these media. The Ministry of Health, Labor and Welfare made a press release on the fatal severe fever with thrombocytopenia syndrome case due to a cat bite to call attention to this problem. ${ }^{34}$ Anther 4 cases of death from Capnocytophaga canimorsus ( 1 case from a $\operatorname{dog}^{35}$ ), Pasteurella multocida ( 2 cases from cats ${ }^{36,37}$ ), and Corynebacterium ulcerans ( 1 case from a $\mathrm{cat}^{38}$ ) infection due only to contact with mammals have been reported; however, these are academic case reports and have not been in the media. We think it is necessary to inform people about the risk of infectious diseases caused by attacks or contact with cats and dogs. There are few case reports of death due to direct injury due to mammals, ${ }^{22,23}$ although there are some characteristic reports that identified the offending animals by analysis of stomach contents ${ }^{24,25}$ or by comparisons of a dental cast with the victim's wounds. ${ }^{26}$

\section{LIMITATIONS}

Our study has several limitations. We could not collect all accidents. Newspapers and other media primarily publish only newsworthy accidents. It is possible that deaths of workers related to livestock or race horses and animalrelated traffic deaths of transporters may be considered less newsworthy. Articles published in the local media might not have been detected. As a result of an online search, 1 case was confirmed only in a government report other than popular media, but this government report was not published regularly. There may be other similar reports. In addition, cases in which individuals were severely injured at the time of the press release and subsequently died may have been overlooked. Among the cases collected, some of the certified occupational accident reports could not confirm the age of the victim. Deaths due to mammal-related traffic accidents may include cases that have not been certified as occupational accidents, even during commuting or working.

\section{Conclusions}

Accidental deaths related to mammals during or outside of work were not common but occurred annually. We concluded that it is important to continue to help livestock farmers and horse race-related workers to prevent accidents, as these groups have a high percentage of fatalities. In addition, regardless of work, it is necessary to call attention to attacks and traffic accidents caused by wild animals moving into human settlements. It is also necessary to inform people about the risk of infectious diseases caused by attacks or contact with dogs and cats.
Author Contributions: Study concept and design (AH); acquisition of data (AH, RI); analysis of data (AH, RI); drafting of manuscript $(\mathrm{AH})$; critical revision and approval of final manuscript (AH, RI).

Financial/Material Support: None.

Disclosures: None.

\section{References}

1. Langley RL. Animal-related fatalities in the United States-an update. Wilderness Environ Med. 2005;16(2):67-74.

2. Ghasemzadeh I, Namazi SH. Review of bacterial and viral zoonotic infections transmitted by dogs. J Med Life. 2015;8(Spec Iss 4):1-5.

3. Creech TG, Fairbank ER, Clevenger AP, Callahan AR, Ament RJ. Differences in spatiotemporal patterns of vehicle collisions with wildlife and livestock. Environ Manage. 2019;64(6):736-45.

4. Austin CC. Nonvenomous animal-related fatalities in the United States workplace, 1992-1994. J Agromedicine. 1998;5(1):5-16.

5. Langley RL, Hunter JL. Occupational fatalities due to animal-related events. Wilderness Environ Med. 2001;12(3): 168-74.

6. Sheldon KJ, Deboy G, Field WE, Albright JL. Bull-related incidents: their prevalence and nature. J Agromedicine. 2009;14(3):357-69.

7. Ministry of Health, Labour and Welfare. Workplace safety website - Fatal accident database [in Japanese]. Available at: http://anzeninfo.mhlw.go.jp/anzen_pg/SIB_FND.aspx. Accessed June 1, 2020.

8. Japan Local Government Employee Safety and Health Association. Current status of accidents in official duties [in Japanese]. Tokyo: Japan Local Government Employee Safety and Health Association; 2002-2020.

9. Statistics Bureau, Ministry of Internal Affairs and Communications. e-Stat. Vital statistics [in Japanese]. Available at: http://www.e-stat.go.jp/SG1/estat/GL08020101. do?_toGL08020101_\&tstatCode $=000001028897 \&$ request Sender=dsearch. Accessed September 24, 2020.

10. Ministry of the Environment. Welfare and proper management of animals. Handbook of administrative affairs on animal welfare and management [in Japanese]. Available at: https://www.env.go.jp/nature/dobutsu/aigo/2_data/ statistics/gyosei-jimu.html. Accessed June 1, 2020.

11. Ministry of the Environment. Statistics on wild birds and animals [in Japanese]. Available at: https://www.env.go.jp/ nature/choju/docs/docs2.html. Accessed June 1, 2020.

12. Forestry and Timber Manufacturing Safety \& Health Association. List of forestry work-related mortality accidents [in Japanese]. Available at: http://www.rinsaibou.or.jp/ cont03/items01/0301_idx.html\#h30. Accessed June 1, 2020 .

13. Suzuki M. Capnocytophaga canimorsus infection caused by dog/cat-bites/scratches [in Japanese]. Modan Media (Modern Media). 2010;56(4):71-7.

14. Matsuda K, Nakagawa T, Okada Y, Shimada T, Kitazawa Y, Ueda R, et al. A case of septic shock caused by Capnocytophaga canimorsus associated with cat bites [in 
Japanese]. Mitsubishi Kobe Byoin Shi (J Mitsubishi Kobe Hosp). 2015;5:29-33.

15. Yamamoto $Y$, Inagaki A, Shimamura $H$, Yazawa J, Iigusa M, Nagano E, et al. A case of sepsis due to Capnocytophaga canimorsus with lightning purpura and DIC [in Japanese]. Sai Rin Gi Kaishi (Saitama J Med Technol). 2015;61(4):270-5.

16. Nakayama I, Mori H. An autopsy case of Capnocytophaga canimorsus sepsis after dog bite [in Japanese]. Nippon Shuchu Chiryo Igakkai Zasshi (J Jpn Soc Intensive Care Med). 2016;23(Suppl):521.

17. Ogasawara N, Ando K, Murata Y. A case of Capnocytophaga canimorsus severe sepsis due to a dog bite that could not be saved [in Japanese]. Nippon Shuchu Chiryo Igakkai Zasshi (J Jpn Soc Intensive Care Med). 2016;23(Suppl):670.

18. Mizutani A, Kato T, Takamiya M, Mori H, Nakayama T, Yano K, et al. A case of death due to sepsis and multiple organ failure due to Capnocytophaga canimorsus infection after dog bite [in Japanese]. Nippon Kyukyu Igakkai Chubu Chihokai Zasshi (Chubu J Jpn Assoc Acute Med). 2017;13:18-21.

19. Asaki M, Masuda T, Uruchida K, Yasuda K, Suzuki M, Imaoka K, et al. A case of fulminant septic shock caused by Capnocytophaga canimorsus infection raced to the emergency room due to cardiopulmonary arrest several days after a dog bite [in Japanese]. Nippon Kyukyu Igakkai Zasshi (J Jpn Assoc Acute Med). 2020;31(1):29-34.

20. Takemoto M, Okamoto K, Fukuda K, Ro H, Imoto N, Nakazawa T, et al. A case of septic shock due to Pasteurella multocida following a minor cat scratch [in Japanese]. Nippon Shuchu Chiryo Igakkai Zasshi (J Jpn Soc Intensive Care Med). 2012;19(2):231-5.

21. Tsuru M, Matsui Tokunaga M, Tanaka S, Saijo M, Shimojima M, et al. A case of severe fever with thrombocytopenia syndrome (SFTS) caused by a cat bite [in Japanese]. Kansenshogaku Zasshi. 2018;92(5):724.

22. Ninomiya K, Ihama Y, Fukasawa M, Kawakami Y, Nagai T, Fuke C, et al. An autopsy case of blunt trauma caused by a bullfight [in Japanese]. Nippon Hoigaku Zasshi. 2014;68(2):321.

23. Oshima T, Ohtani M, Mimasaka S. Injury patterns of fatal bear attacks in Japan: a description of seven cases. Forensic Sci Int. 2018;286:e14-9.

24. Irisawa Y, Imamura S, Nakamura H. Fatal case due to dog bite [in Japanese]. Nippon Hoigaku Zasshi. 2004;58(1):92.

25. Tsuji A, Ishiko A, Kimura H, Nurimoto M, Kudo K, Ikeda N. Unusual death of a baby: a dog attack and confirmation using human and canine STRs. Int J Legal Med. 2008; 122(1):59-62.

26. Oshima T, Mimasaka S, Yonemitsu K, Kita K, Tsunenari S. Vertebral arterial injury due to fatal dog bites. J Forensic Leg Med. 2008;15(8):529-32.

27. Ministry of Agriculture, Forestry and Fisheries. Safety measures for farm work. Investigation of fatal accidents during farm work [in Japanese]. Available at: http://www. maff.go.jp/j/seisan/sien/sizai/s_kikaika/anzen/\#sibochosa. Accessed June 1, 2020.

28. Horse Racing School, Japan Racing Association. Guidelines on managing and handling racehorses [in Japanese]. Shirai, Chiba: Horse Racing School; 2015.

29. Liaison council on occupational accident prevention in competitive horse-breeding. Occupational accident prevention manual in competitive horse-breeding [in Japanese]. Urakawa: Urakawa Labour Standards Inspection Office; 2015.

30. Ryugasaki Labour Standards Inspection Office. Number of occupational accidents in Miho Training Center has turned downward [in Japanese]. Public information of Ryugasaki Labour Standards Inspection Office. 2017-2-8.

31. Ministry of the Environment. Notification of animal care and storage [in Japanese]. No.1703152 Notice of the director of General Affairs Division, Natural Environment Bureau, Ministry of the Environment. March 15, 2017.

32. Okano I, Midorikawa Y, Kushima N, Watanabe Y, Sugiyama T, Mitachi K, et al. Penetrating anorectal injury caused by a wild boar attack: a case report. Wilderness Environ Med. 2018;29(3):375-9.

33. Oishi Y, Iwata A, Fujita M. Local newspaper news production process: a case study of Ibaraki Shimbun [in Japanese]. Media Communication (Keio Media Commun Res). 2000;No.50:65-86.

34. Ministry of Health, Labour and Welfare. Alert about severe fever with thrombocytopenia syndrome (SFTS) [in Japanese]. No.0724:1-3 Notice of the director of Tuberculosis and Infectious Diseases Control Division. Health Service Bureau, Ministry of Health, Labour and Welfare; July 24, 2017.

35. Imamura $T$, Matsuyoshi $T$, Hirose $Y$, Sumita $K$, Watanabe T, Yamaguchi K, et al. A case of septic shock caused by Capnocytophaga canimorsus in a pet beloved person [in Japanese]. Nippon Kyukyu Igakkai Kanto Chihokai Zasshi (Kanto J Jpn Assoc Acute Med). 2013;34(2):239-42.

36. Tsukadaira A, Nogami A, Yanagida N, Jitsuhara M, Hoshinoo K. A fatal case of septicemia by serotype A:3 Pasteurella multocida in human: review of 14 septic cases in Japan [in Japanese]. Rinsho Byori. 2014;62(5):427-31.

37. Tajima J, Miyake N, Inoue Y, Kumagai K, Hirose Y. A case of Pasteurella multocida meningoencephalitis that was transported on suspected heatstroke and died rapidly [in Japanese]. Niigata Shimin Hospital Ishi (Med J Niigata City General Hosp). 2016;37(1):91.

38. Otsuji K, Fukuda K, Endo T, Shimizu S, Harayama N, Ogawa M, et al. The first fatal case of Corynebacterium ulcerans infection in Japan. JMM Case Rep. 2017;4(8): $\mathrm{e} 005106$. 